\title{
The Making and Unmaking of a Bullying Victim
}

\author{
Michael Tholander ${ }^{1}$
}

Received: 3 July 2018 / Accepted: 7 February 2019 / Published online: 14 February 2019

(C) The Author(s) 2019

\begin{abstract}
This study focuses on a video-recorded meeting in which a 13-year old female student, in front of her teacher and parents, discloses that she is being bullied. Through a combination of a conversation analytic approach and a victimological perspective, the analyses center on how the student frames her own victimhood narrative as well as on how the other participants, mainly the teacher, respond. While the student in observable ways strives to portray herself as a genuine bullying victim, she nevertheless, after encountering a series of discursive practices, ends up as a rejected victim. This could potentially lead to a form of secondary victimization, in which the original suffering of the victim is exacerbated through inadequate responses by third parties. Three implications for teachers in similar positions are highlighted: (1) Thoroughly scrutinize your own discursive environment, (2) take every victimhood narrative seriously, and (3) solve the problem without delay.
\end{abstract}

Keywords Bullying · Conversation analysis · Discursive repertoires · Secondary victimization $\cdot$ Victimology $\cdot$ Victim status

Since its inception, school bullying research has dwelt on definition issues (e.g., Olweus 1973; Smith et al. 2002; Volk et al. 2014). The most commonly used definitions typically suggest that bullying practices are intentionally performed hostile acts that are repeated over time and substantiate an already existing power imbalance. In this article, the definition of bullying is also of central importance, although here I am more interested in the studied participants' interactionally displayed understandings than in my own understanding as a researcher. My argument is that the ways in which the participants frame their talk about a possible bullying case suggest that this type of retrospective, defining talk is considerably more influential for the outcome of the case than the original events.

Michael Tholander

michael.tholander@liu.se

1 Department of Behavioural Sciences and Learning, Linköping University, 58183 Linköping, Sweden 
More specifically, the article focuses on a video-recorded piece of interaction in which a 13-year old female student, as part of a meeting together with her teacher and parents, reveals that she is being bullied. She does so not by using the term "bullying," but by recounting events from daily life in school. The analyses focus in detail on the student's framing of her own victimization as well as on the reception it gets from the teacher and the parents. Despite being one of the most recommended strategies to stop school bullying (Black et al. 2010), numerous studies show that students often do not disclose to their teachers and parents that they are being targeted (Bjereld 2016; deLara 2012; Frisén et al. 2008). This "culture of silence" (Smith and Shu 2000, p. 193) is perhaps also strengthened by the fact that teachers and parents, in turn, often do not intervene even when they do get informed about bullying (Ellwood and Davies 2010; Merten 1997; Thomson and Gunter 2008). Against this background, the present study provides a unique opportunity to follow, in detail, how a student does indeed disclose that she is being bullied, and how the teacher and the parents in turn respond to this disclosure.

Methodologically, the study subscribes to a social constructionist framework (Burr 1995) and is inspired by conversation analysis (Hutchby and Wooffitt 2008). The focus on the participants' perspectives is a central tenet of the latter approach, and it is typically accomplished through detailed analysis of recorded and transcribed naturalistic interaction. Often, this type of conversation analytic study is fashioned in a rather atheoretical way, but in the present study, I provide detailed analyses of conversational practices from a victimological perspective. It is my argument that victimology can be a particularly useful tool in the scrutiny of how bullying, and more specifically a victim, is constructed and deconstructed in an everyday setting. Observe that the use of the words "making" and "unmaking" in the title of the article does not mean to suggest that the student's victimhood is not real in an empirical sense. Rather, the point is that it is contingent upon a series of more or less sophisticated discursive practices.

\section{A Victimological Perspective on Bullying}

As Rigby (1995) points out, bullying was long regarded as part and parcel of "going to school" (see also Bansel et al. 2009; Dussich and MaeKoya 2007; Mishna et al. 2006). Yet, over the last decades, research has pointed not only to the magnitude of the problem, but also to its pernicious effects. A recent ten-country study shows that being a victim of bullying is associated not only with an increased risk for suicide, but also with various types of self-injurious behaviors (Brunstein Klomek et al. 2016). For the victims, gloomy prospects also continue into adulthood, with longterm psychological (Takizawa et al. 2014), social (Wolke et al. 2013), and physiological effects (Copeland et al. 2017). Altogether, this makes bullying a societal problem of enormous dimensions, and bullying targets are now undeniably regarded as true and legitimate victims, although almost never in a judicial sense.

Despite this development, bullying researchers have generally not turned to victimology, a subfield of criminology, for theoretical inspiration and guidance. One reason for this might be that the field of victimology has been more attractive to 
researchers with a focus on children as victims of adult perpetrators (Rigby 1995). When "only" children are involved in questionable events, there is perhaps a tendency to consider what has happened, both formally and informally, as less of a "real" crime. Yet, a victimological perspective can be valuable quite independently of whether or not bullying is understood as criminal activity. I clarify below how I use victimology as a tool in my research.

In particular, I lean on what McGarry and Walklate (2015) refer to as "critical victimology," which "puts to the fore the processes that create the victims we 'see' as well as the ones we do not "see"” (p. 13). In my case, where there is only one potential victim, the analytical task is thus to study the precise social processes that contribute to the shaping and reshaping of this victim. As has already been made clear above, this includes a focus on the contributions of all the participants of the studied meeting: The student, the teacher, and the parents. Together they prove Christie's (1986) thesis that being a victim is not an objective phenomenon, but has to do with the participants' definition of the situation. Thus, to acquire victim status, or to become a victim "in a socially relevant sense" (Stroble 2010, p. 3), an individual must pass as a victim in a public or collective situation. In this regard, it is possible to differentiate between two types of "social victim statuses," which are both relevant in the case being analyzed.

The first type of victim status consists of a continuum, where the extreme positions are represented by "the ideal victim" and "the non-ideal victim." In between, there is a potentially unlimited series of positions to occupy, but in order to qualify as "the ideal victim" (Christie 1986, p. 18), i.e., as someone who is accorded complete victim status, you need to fulfill a number of criteria. For instance, the ideal victim is generally, and in a relative sense, well-intentioned, innocent, weak, etc. The precise type of victim label that is relevant in a particular situation, e.g., "blameless," "feckless," or "deserving" (Mythen 2007, p. 476), is open to negotiation, but, of course, this is often only implicitly articulated among the participants. Moreover, the more ideal a victim is, the more ideal the offender becomes - and vice versa (Christie 1986). Thus, in order to pass as a bullying victim, the student in this study must succeed in both these respects.

The second type of victim status consists of four positions, which depend on whether or not the individual is acknowledged as a victim by the social environment and by him/herself (Stroble 2010). Thus, in a $2 \times 2$ matrix, the following statuses can be found: (1) actual victim (someone recognized by themselves and others as a victim); (2) non-victim (someone not regarded as a victim by themselves or others); (3) rejected victim (someone seen as a victim by themselves, but not by others); (4) designated victim (someone viewed as a victim by others, but not by themselves). As we shall see, the student in this study seems to strive for the position of actual victim, but ends up as a rejected victim, or perhaps even as a non-victim.

In analyzing the case, I start by focusing on how the student frames her own victimhood narrative. I then point to a number of discursive repertoires that the teacher in particular draws on in her response to the narrative. Through these repertoires, the teacher manages to dismantle the student's narrative, make the possible bullying seem more like mundane school matters, and defend her own status as a professional teacher. Whether we view these repertoires as varieties of "bully discourses" 
(Ringrose and Renold 2010, p. 575), "shared cultural understandings" (Hein 2014, p. 310), or, more cynically, "glib cliché" (Walton 2015, p. 26), the net result is the same: They play a decisive part in the formation, or rather deformation, of the student's victim status.

More generally, the use of the identified repertoires, or similar ones, might explain why victims of bullying often complain about the lack of adequate support (Bjereld 2016; deLara 2012; Oliver and Candappa 2007). Through such repertoires, they are exposed to a "capillary form of power" (Foucault 1980, p. 39), which, precisely because of its infinitesimal mechanisms, is very hard to resist. Indeed, they may even be subjected to what victimologists refer to as "secondary victimization" (Stroble 2010, p. 15), i.e., various problematic reactions by third parties that exacerbate victims' original suffering.

\section{Methodological Issues}

The analyzed episode has been singled out from a corpus of video-recorded "developmental dialogues" in which students, teachers, and parents, in three-party meetings, discuss the past and future school lives of the sixth-grade students concerned. Hence, there was no original plan to focus on talk on bullying, but the episode was discovered serendipitously during the research process. More specifically, I focus on five minutes of a 35-minute long session with four participants: The female teacher, the sixth-grade student (given the pseudonym "Disa"), and both of Disa's parents. The episode was transcribed in its entirety using symbols (see "Appendix 1") matching those developed by Jefferson (2004). All data were initially transcribed and analyzed in their original Swedish form and only later translated into English. Given space limits, excerpts from the original Swedish transcript are not presented.

In general, conversation analysis studies seek to describe the structure of a coherent conversational phenomenon, how it is organized, and the practices by which it is produced (Schegloff 1996). However, studies may also, as in the present case, concentrate on a single sequence of talk and analyze a range of different phenomena occurring within it. This is known as "single case analysis" and is aimed less at producing generalizable findings and more at analyzing "the various conversational strategies and devices which inform and drive its production" (Hutchby and Wooffitt 2008 , p. 114). Yet, as pointed out by Stake (1978), case studies might still provide opportunities for "naturalistic generalization," i.e., a kind of generalization that is left to the reader to perform on the basis of his or her prior experiences and knowledge — or lack thereof. Moreover, case studies are an important means of acquiring "vicarious experience," i.e., knowledge that arrives through the (indirect) observation of others.

In a similar vein, Jaspers (1959/1963) argues that close examination of a single case often teaches us of phenomena that are common to countless other similar cases. Thus, he continues, it is "not so much the number of cases seen that matters [...] but the extent of the inner exploration of the individual case, which needs to be carried to the furthest possible limit" (p. 56). Through conversation analysis, with its specific focus on the detail of interactions, this "inner exploration" can reach new 
levels. Indeed, with close inspection of meticulously transcribed interactions, we can discern human practices that, at the outset, we would not even have realized were there (Sacks 1984).

This blindness to daily practices certainly applies to the participants as well, as Potter (1996) points out. After years of practice, people perform actions without being consciously aware of them, and without being the most qualified to comment on them. Thus, Foucault's often quoted assertion that "People know what they do [...] but what they don't know is what they do does" (Dreyfus and Rabinow 1982, p. 187) can be questioned. From a conversation analytic standpoint, the argument is rather that the participants often do not know what they do-simply because their doings often occur as finely-tuned habitual doings - and that they therefore must be even less aware of what they do does. The methodological implication of this is clear: There is no reason to moralize over the participants, even though specific practices can certainly be called into question. Instead, we should focus on the actions that participants accomplish through their ways of speaking, and, thereby, contribute to an increased understanding of the problems such actions might potentially create.

Indeed, what is fascinating about a case is often not the case in itself, but precisely the actions that are accomplished in it. Every case is undoubtedly unique in its details, happening only once in world history, but the actions in it belong to our contemporary culture and we can assume that they are reproduced over and over again. As Merleau-Ponty (1945/2002) argues, certain ways of speaking and acting become "sedimented" in people and come to the fore more readily than others- they acquire "a favoured status" (p. 513). Thus, when the participants in this study interact, drawing on the deep reservoir of lived experience, common sense, developmental psychology, etc., they collectively enact an "unreflected ordinariness" (Davies 2011, p. 282) that can be assumed to be far from unique in its broader sketches.

The study was conducted in concordance with the ethical principles of research in Sweden, including informed consent, confidentiality, and usage rules (see Swedish Research Council 2011). As this particular type of research does not fall under "The ethical review act" (SFS 2003, p. 460), ethical clearance was not required.

\section{Results}

This results section consists of eight excerpts from the transcribed 5-mins episode, each with attached analyses. In the first excerpt, Disa presents her victimhood narrative, and in the subsequent seven, we can follow the resulting discussion among the participants. The excerpts are presented chronologically, each with a time notification.

\section{Coming Out as a Bullying Victim}

When we enter Excerpt 1, Disa starts to read from a paper that she has prepared beforehand (and which the teacher has already read). In this way, she manages to take a protracted turn and explicate her case. The analyses following the excerpt 
focus specifically on the ways in which Disa frames her own victimization (highlighted in italics). This framing reveals what she deems essential in order to qualify as a bullying victim, and implicitly delivers a definition of bullying from an insider's perspective.

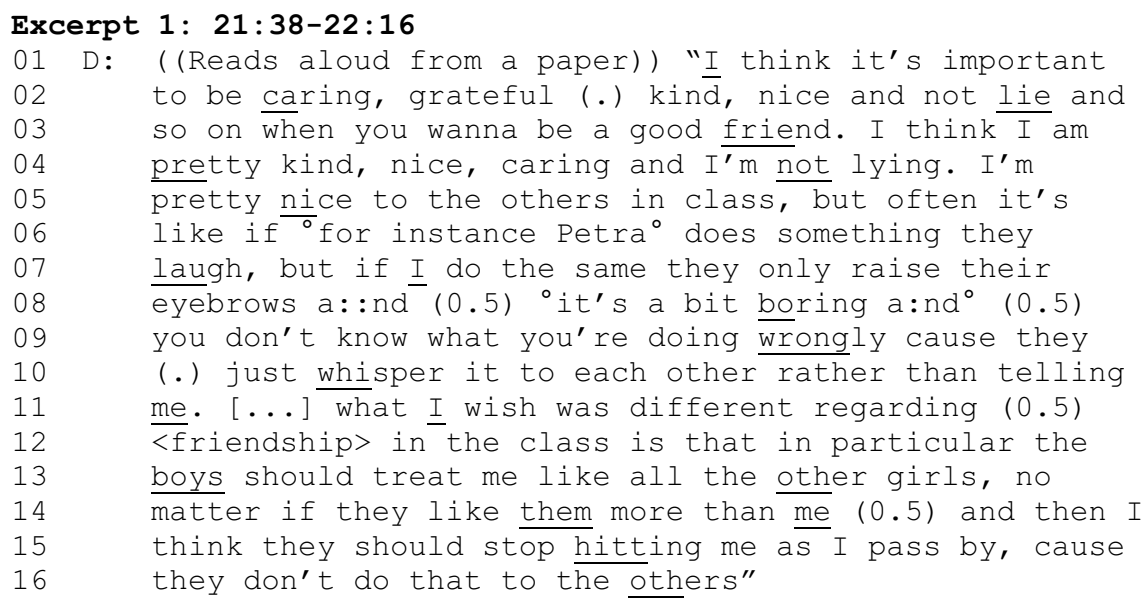

Disa starts off by portraying herself as "a good friend." Not only does she have the right attitude, "I think it's important to be" (L1-2), but she also claims to implement this attitude in daily school life, "I think I am" (L3). It is vital for Disa to assume this identity of a good friend in her victimhood narrative. The ideal victim is completely innocent, preferably even having no prior relationship to the offender (Christie 1986). Yet, Disa has spent considerable time in this class and cannot claim to be unknown to anyone. It is thus essential for her to be able to argue that she is "pretty nice to the others in class" (L5), and to clarify that she is not the target of what has been called "reactive aggression" (Volk et al. 2014, p. 329), i.e., that she has contributed to her own victimization by engaging in questionable actions previously. Indeed, given that teachers, parents, and students often seem to share the view that victims bring it on themselves (Ringrose and Renold 2010), it becomes even more important for Disa to inoculate herself against potential charges of victim precipitation. "Unprovoked bullying" and "provoked aggression" are often in opposition to each other, and if there are "faults on both sides" (Søndergaard 2012, p. 363), the result can easily be a no-action policy.

Another important part of Disa's narrative is the argument that, in two distinct senses, she is subjected to repeated differentiating treatment in comparison with her peers. First, Disa describes two archetypical forms of bullying, direct and indirect, and also links them to gender in a predictable way (see Olweus 1993). Thus, while the girls repeatedly belittle her by raising their eyebrows (L7-8), the boys repeatedly hit her as she passes by (L15). Second, Disa also claims to be a marked victim in another sense: Her peers not only escape the treatment she is exposed to, but in fact experience the reverse treatment. This is true in particular 
of her female assailants, who laugh at each other's jokes rather than raise their eyebrows (L6-8). It seems obvious that when Petra, the girl taken as an example, does or says something, this constitutes an important "positioning tool" (Søndergaard 2012, p. 358) through which she marks herself as special. However, when Disa attempts the same thing, she finds herself to be the positioning tool of others. Being subjected to such repeated and doubly differentiating practices further strengthens Disa's appearance as an ideal victim. She is the Other- "the other as in inferior" (Jensen 2011, p. 65).

An additional aspect of Disa's narrative is the way in which she portrays herself as someone who is willing to change. Previous research has shown that bullying victims often blame themselves, and that they often nurse a desire to belong (Goodwin 2002; Graham and Juvonen 1998; Silberschmidt Viala 2014). Disa implicitly confirms both these tendencies by making another complaint about her social situation: "you don't know what you're doing wrongly cause they (.) just whisper it to each other rather than telling me" (L9-11). Thus, if only Disa's peers were caring enough to inform her of her faults, she would be able to adjust accordingly. Instead, her willingness to change is met by whispering that excludes her and thus adds to the bullying and to her outsider position. This also tags on a new dimension to her appeal as an ideal victim: Although she already lives up to the ideals of being "kind," "nice," and "caring" (L4), she is not even afforded the chance to know how she can better herself even more.

A final aspect of Disa's narrative that helps bring her closer to the status of an ideal victim is that she rather explicitly makes it clear that she does not demand to be the most liked girl in the class. Thus, while unassumingly putting forward her "wish" to be treated like the other girls (L11-13), she also humbly adds that this wish in no way implies that the boys must give up their already established preference hierarchy; they should instead be permitted to "like them more than me" (L14). This demonstrates that she is a victim who does not have unrealistic pretensions, but who only wants to rid herself of degrading peer cruelties.

The only thing that Disa says that works in the opposite direction, i.e., in countering the construction of an ideal victim status, is when she comments silently, as if she were talking to herself, on being subjected to raised eyebrows by the girls: "it's a bit boring" (L8). Without knowing the full nature of Disa's situation, one thing that is accomplished by this mitigated formulation is that Disa protects her parents from full exposure to the suffering she is presumably going through. The ultimate alternative would perhaps have been to start crying after recounting the mortifying treatment, especially as bullying victims that do not match our expectations about how victimized children behave risk being disregarded as victims (Mishna et al. 2006). Yet, previous research also shows that children often wish to maintain their status as non-victims, in order to protect both themselves (Bjereld 2016) and their parents (Mackay et al. 2011). One way to accomplish the latter is to remain completely silent about the bullying. Another way is to do as Disa does: To speak up about the bullying, but without using the label and to frame it in a rather unemotional way. 


\section{Empirical Testing, Out-there-ness, and Immaturity}

We have studied above, in detail, how Disa quite skillfully establishes herself as a victim of bullying. In many respects, she matches the template of the "ideal victim," and we therefore have good reason to expect her to achieve the status of "actual victim," i.e., as someone regarded as a victim not only by herself, but also by her social environment. However, we see below how Disa instead becomes a "rejected victim" or even a "non-victim." Throughout the analyses, I identify a number of discursive practices that contribute to this process. When we enter Excerpt 2, Disa has just finished her victimhood narrative.

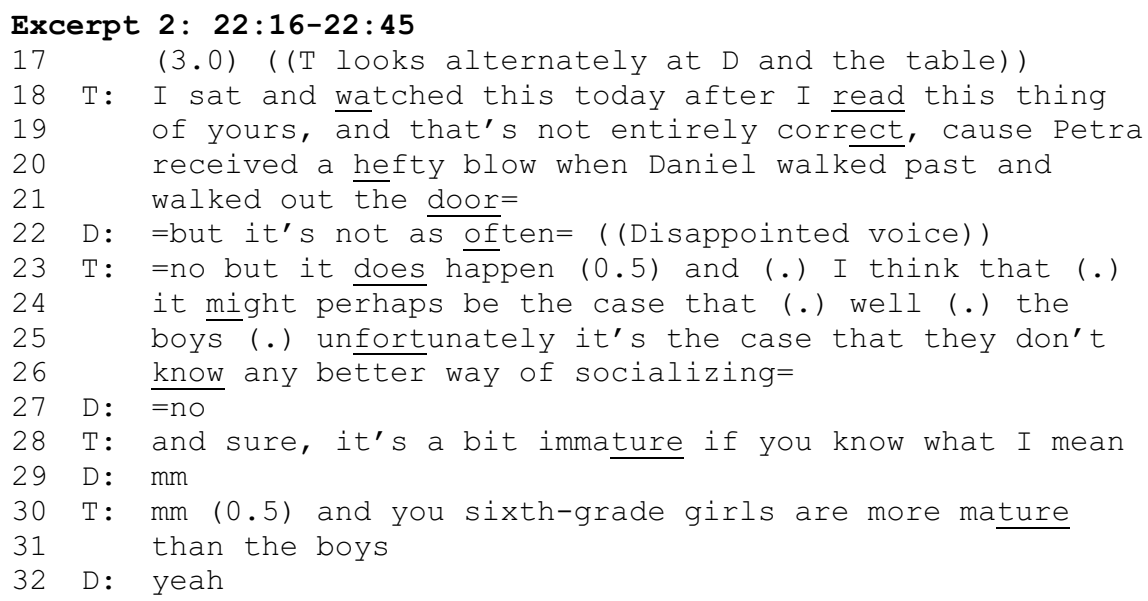

After listening to Disa's prolonged turn, it is quite natural to expect an initial response from the teacher as she is in the most accountable position, being responsible for both the meeting and the school class. If no response were to be forthcoming, it would be noticeably absent, the preferred response (culturally, psychologically, structurally, etc.) perhaps being one of empathy and further enquiry. In comparison with these alternatives, the teacher first lingers over her answer (L17), bordering on being noticeably absent, and then delivers a reply that is far from empathic or enquiring, instead revealing that she has empirically tested Disa's assertion during the day (L18-21). Thus, reminiscent of the use of the "empiricist repertoire" in scientific disputes (Gilbert and Mulkay 1982, p. 383), she declares Disa's account defective on the basis of her own careful observations of "reality": "I sat and watched this today [...] and that's not entirely correct" (L18-19). Although the teacher here does not explicitly accuse Disa of "playing the victim," a practice that Mishna et al. (2006) noted among her teachers, her response at least converts Disa into an exaggerator or a drama queen. Moreover, this response constitutes an important first step in transforming the potential bullying problem into something less serious.

Disa's immediate response to the teacher is to argue that she is a victim who is particularly affected: The others are not hit "as often" (L22). As observed in Excerpt 1, 
Disa both explicitly (L5) and implicitly (L15) claimed to be subjected to "repeat victimization" (Goodey 2005, p. 59), but now she adds a comparative (relative rather than absolute) dimension to this, which makes her even more of a victim, perhaps even meeting the requirements for what victimologists describe as the chronically victimized (Farrell 2010). However, this reply from Disa is also the last one in which she insists that she is in an exposed situation. Her only contributions during the ensuing minutes of analyzed interaction are the following one-syllable or non-verbal signals: no; mm; yeah; mm; mm (.) yeah right; yeah; mm; mm; mm (0.5) mm; mm; yeah; no; mm; mm; $\mathrm{mm} ;{ }^{\circ} \mathrm{yeah}^{\circ} ;{ }^{\circ} \mathrm{mm}^{\circ}$; nods slightly; ${ }^{\circ} \mathrm{no}^{\circ}$; nods slightly; nods slightly; $\mathrm{mm} ;{ }^{\circ} \mathrm{mm}^{\circ} ;{ }^{\circ} \mathrm{mm}^{\circ}$; ${ }^{\circ}$ yeah $^{\circ}$ (see Excerpts 2-8). As we shall see, this partial silencing of Disa is accomplished through a sophisticated, though not necessarily conscious, display of discursive practices, mainly enacted by the teacher.

We have already noted the empiricist repertoire deployed above, but now the teacher introduces an "immaturity repertoire" in response to Disa's victimhood narrative. In essence, this repertoire states that the boys' hitting of Disa (and other peers) can be understood as a clumsy way of seeking contact, which is only to be expected from immature boys of their age (L23-26, 28). Notice also how the teacher's shift from "it might perhaps be the case" (L24) to "unfortunately it's the case" (L25) creates a kind of "out-there-ness" (Potter 1996, p. 153) of the boys' immaturity. In this way, the immaturity of the boys becomes a fact that is independent of its producer. It draws attention away from the question of the teacher's stake in the fact construction, i.e., what she might gain from it, for instance in terms of deflecting responsibility away from herself. Moreover, because the argument repeatedly invites approving responses, it creates a difficult rhetorical situation for those not wishing to agree (see Edwards et al. 1995). For instance, it is very difficult for Disa to protest against the compliment that the girls, as a group, are given at the end of the excerpt (L30-31). However, this compliment, as well as Disa's "yeah" (L32), contributes to a kind of normalization of the boys' immature behavior. Not only the teacher, but developmental psychology in general, conveys this picture of girls being more mature than boys, e.g., in relation to the display of interactive skills (Maccoby 2000). Thus, as Hepburn (1997) points out, teachers' explanations of bullying often mirror the psychological literature.

\section{Normal Problem, Promising Future}

In Excerpt 3, below, I point to further examples of the normalization of boys' putative aggressive tendencies, but also to the dilemma the teacher faces when she enters into this kind of discourse. The teacher points to three ways out of the dilemma, and they all have a role in making Disa less of a victim. 


\section{Excerpt 3: 22:49-23:18}

$36 \mathrm{~T}$ : unfortunately we do have some boys in class that have

37 been in fights- (.) have been smacking and puching

38 classmates ever since they were kids

39 D: $\mathrm{mm}$

$40 \mathrm{~T}$ : and of course we talk about this a:ll the time

$41 \mathrm{M}: \mathrm{mm}=$

42 T: =bu:t (.) we:ll it i::s (.) hard to solve this. (1.0)

43 let's hope that smacks and puches are not their means

44 of seeking contact when they turn twenty-five heh but

45 heh that heh they [have learnt a better way by then

46 F: [exa:ctly!

47 T: e:h and it usually gets- (.) I think it's better now

48 [than it was in fourth grade

49 D: $[\mathrm{mm}($.$) yeah [\mathrm{right}$

50 T: [do $\underline{\text { you }}$ think so as well?=

51 D: =yeah

52 T: yeah there's getting to be a bit more talk and

conversation than just this body contact

At the beginning of the excerpt, we can note how the teacher points to the boys' aggressiveness as a long-term problem (L36-38) and the difficulty of solving it (L42). More specifically, the formulation "have been smacking and puching classmates ever since they were kids" (L37-38) strongly contributes to the normalization of the problem. First, it once again transforms Disa into merely one victim among a series of others. Second, it implies that the specific boys had this behavioral trait from the very beginning, thus absolving the teacher or the school from guilt. Yet, this normalization also creates a professional dilemma: Taking this view of the problem means there is nothing you can do, and "brute reality" may lead to inaction, frustration, and hopelessness. The teacher solves the dilemma in three ways, all of which affect Disa's victim status.

First, by emphasizing that she keeps talking to her class about the problem "a:1l the time" (L40), the teacher conveys the impression that she is taking action on problems, upholding her agential power despite working against nature. Thus, neither Disa nor anyone else is an abandoned victim. Second, by making a joke that she hopes the boys will eventually discard "smacks and puches" as a way of seeking contact as adults (L43-44), the teacher not only converts the culprits into pitiable males, but also suggests that their overt physical violence in reality represents an amorous interest. Mishna et al. (2006) argue that this way of attributing benign meaning to problematic behavior, in this case through a romantic repertoire, is a part of viewing boys as immature. Finally, by arguing that the boys have already improved (L47-48), and, yes, even engaged in "talk" and "conversation" (L52-53), the teacher instills hope for the future. Perhaps their violence should not even be conceived of as bullying, but rather as an integral part of a prolonged developmental stage that certain afflicted boys must grow out of (see Ringrose and Renold 2010). 
The teacher's use of an euphemism, "this body contact" (L53), which replaces Disa's use of "hitting" in Excerpt 1 (L15), supports this interpretation.

\section{Standing Up Against the Primitive Others}

In Excerpt 4, below, the teacher continues to talk about the boys as a group, and finishes off with a piece of advice to Disa. In essence, the violent boys are constructed as the primitive Other, who needs to be challenged by the civilized young woman.

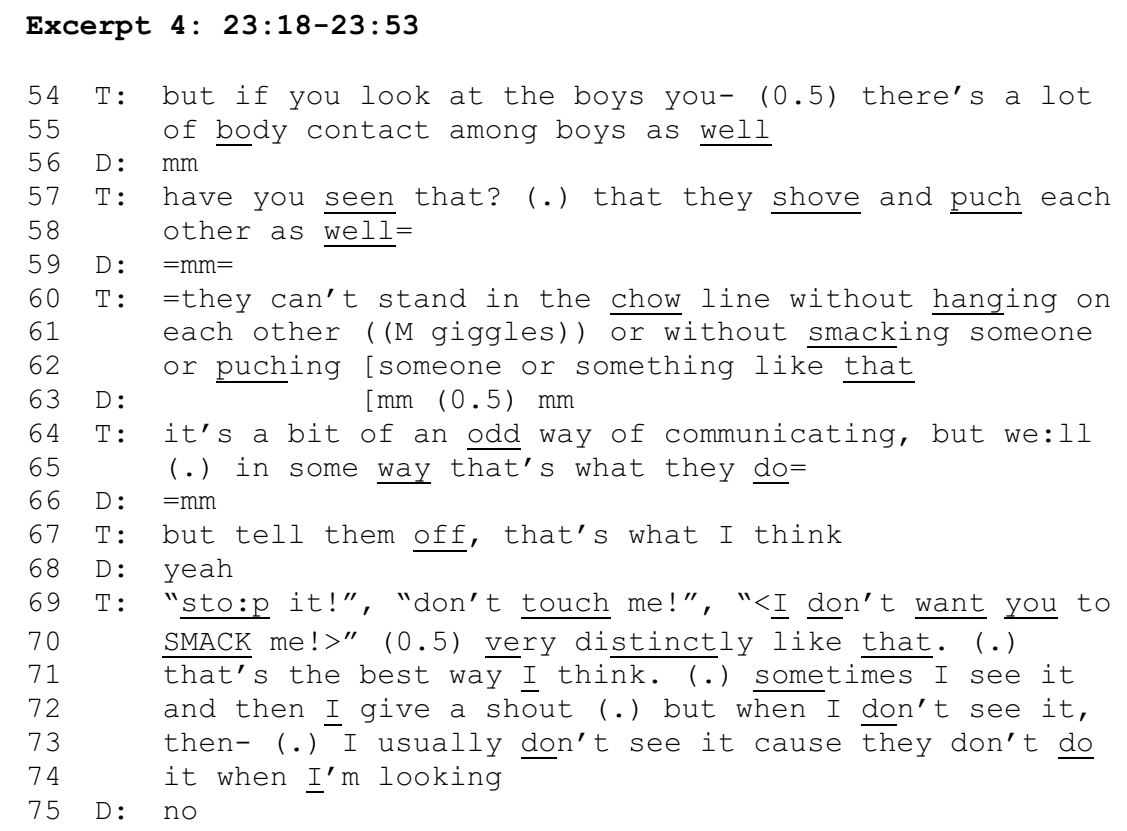

As shown already in Excerpts 2 and 3, the teacher portrayed the boys in ways that bordered on "othering," if by that we mean being reduced "to a few negative characteristics" (Jensen 2011, p. 65). In this excerpt, this tendency is intensified over a series of turns (L54-66). At first, the teacher utilizes a kind of "ubiquity repertoire" in conveying the impression that the boys display a vast amount of aggressiveness in all sorts of situations and towards all sorts of subjects and objects (L54-55, 57-58, 60-62). Then the teacher places herself, and supposedly Disa as well, far above that kind of male behavior: It is "an odd way of communicating" (L64), but "that's what they do" (L65). It is thus an "intelligible" masculinity in that it coheres with commonsense stereotypes (Ringrose and Renold 2010), but it should be noted that it is pathologized at the same time as it is normalized. For Disa, this yet again has the unfortunate side-effect of making her much less of an ideal victim. First, is she not merely one victim among others? Second, should she not just relish the fact that she 
does not belong to that other species? Indeed, it might be that the boys are the true victims.

After this, the teacher introduces what might be characterized as a "self-reliance repertoire." First, she suggests that Disa should stand up against the boys and "tell them off" (L67). Then she suggests a few very specific phrases that Disa could use in response to them (L69-70). In light of the prior normalization of the boys' behavior, as well as her statement that the problem is hard to solve (see Excerpt 3), this might be seen as rather inconsistent advice. If the responsible teacher finds it hard to bring about change, then how can the problem be delegated to the victim? Yet, research shows that adults often recommend that the victim of bullying should resist the bullies with assertive responses (deLara 2012; Hein 2014; Ringrose and Renold 2010). Such a strategy supposedly increases the cost for the bullies and adjusts the power imbalance (Volk et al. 2014), and it is also the most successful coping strategy according to children themselves (Black et al. 2010). Moreover, against the backdrop that bullying often occurs in the interstices of teachers' surveillance practices (Craig et al. 2000; Hamarus and Kaikkonen 2008; Osbeck et al. 2003), this strategy makes even more sense. Indeed, the teacher in the analyzed case trades on this logic while pushing for the self-reliance strategy: "I usually don't see it, cause they [the boys] don't do it when I'm looking" (L73-74). The message to Disa seems clear: As a victim, you must do your own share of protection work, to "man up" (Sims-Schouten and Edwards 2016, p. 1385), and if you have not tried this so far, you are not the ideal victim.

\section{This Other Thing}

In Excerpt 5, below, the teacher suddenly turns to the second aspect of Disa's victimhood narrative, i.e., the girls' differentiating treatment of her. Here, the teacher creates a normalization similar to the previous one. Once again, this also includes the formation of an out-there-ness that deflects responsibility away from the teacher. 




What is noteworthy right at the start of this excerpt is how the teacher returns to the girls' treatment of Disa by referring to it as "this other thing" (L78). In this way, she transforms something that could be labeled as "bullying" into something more vague and ambiguous. Given that Brown et al. (2007) make the point that the label "bullying" is often used as a euphemism for behaviors that could be regarded as more serious harassment, the teacher's labeling variation in the present case is even more softened, once again making Disa much less of a victim. Moreover, and in line with this interpretation, when the teacher continues, she does not topicalize Disa's victimization, but instead fuels "the fact" that Petra can do "almost anything" (L79). The explanation she offers for this is that there are groupings in the class and that two girls have an elevated position (L81-84). The use of the phrase "there are" three times in a row (L81-83), as well as the phrase "that's the way it is" (L86), strongly normalizes this state of affairs, making it clear that it is beyond the teacher's control. Thus, the critical commenting from these high status girls is something that the rest of the girls, not only Disa, obviously have to accept (L86-87). Jacobson (2010) poignantly argues that such acceptance of status hierarchies reproduces school's own systems of comparison and ranking.

Once again, however, this normalization of the problem creates a dilemma for the teacher: By subscribing to what we can call a "status resilience repertoire," the teacher risks undermining her own agential power. Perhaps by way of compensation, the teacher quickly enumerates some actions that point to her own professional initiative: She "[manages] group processes all the time", she "[makes] certain that everything is good", and she deals with things "as soon something happens" (L91-94). In the end, however, the teacher closes the circle and admits that the forces of the natural hierarchization still win: "the status they've got in the class, they'll keep that" 
(L95). Disa seems to wearily agree with this view (L96), and, whether true or false, this myth of a resilient order among children has a long history in social research. For instance, Gästrin (1946) expresses himself very much like the teacher as early as the 1940s: "Children who belong to the upper or lower status group remain there year after year" (p. 108, my translation).

\section{Taking the Chance}

In Excerpt 6, below, the teacher suggests that Disa nevertheless has a chance to escape the locked status hierarchy and thereby the negative treatment. This time, the solution does not depend on the maturation process of her peers, but on Disa taking action on a particular future occasion.

\section{Excerpt 6: 24:35-24:59}

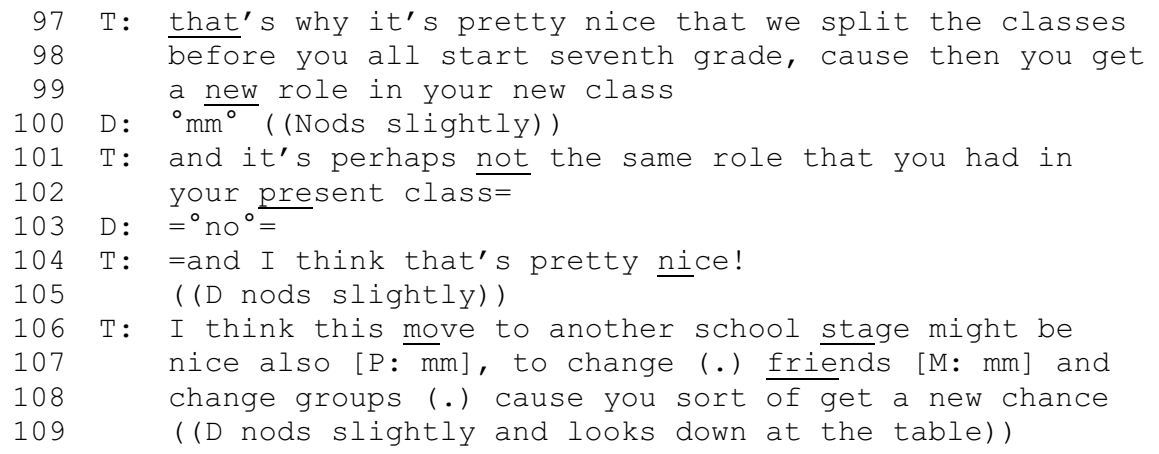

After thoroughly establishing the resilience of status hierarchies, the teacher now points to the upcoming splitting of the classes as a solution to the resulting problems (L97-99). Disa has about 2 months left in the present sixth-grade class, and after the summer she will move to a new class at another school. Although such splitting is merely an organizational feature of the Swedish school system, the teacher here seems to convey the impression that it is designed exclusively to deal with the identified problem. Moreover, the teacher presents it as a definitive fact that this organizational change will also lead to social changes: "then you get a new role" (L98-99). Note also how the teacher, in her next turn, already talks about Disa's current role in the past tense: "that you had" (L101). Obviously, Disa cannot expect a change during her final weeks at the present school. However, this talk of a brighter future still transforms Disa's victim status. She might be a victim now, but a victim who is about to escape her worries is, of course, much less of an ideal victim.

Just as in previous excerpts (e.g., Excerpt 3), the teacher tries to convey her messages in a positive manner (L104, 106-108). However, Disa continues to avoid establishing a shared enthusiasm, and instead replies in a minimalist fashion with hardly noticeable nods (L105, 109). It is possible to read a kind of skepticism into this. Having earlier produced her retrospective victimhood narrative, she now 
finds herself in the midst of a prospective wonderland. In this, she will "get a new chance," and if she does not take it, she might even be considered to be at fault herself. However, research has shown that Disa's skepticism is well founded. For instance, Salmivalli et al. (1998) have shown that even after a "fresh start" (p. 214), victims of bullying often remain in a marginalized position.

\section{Lots of Drama}

In Excerpt 7, below, the mother comments on the girls' group climate, and argues that Disa vacillates between being accepted and rejected. This becomes the start of an othering process concerning the girls similar to the one directed against the boys in Excerpt 4.

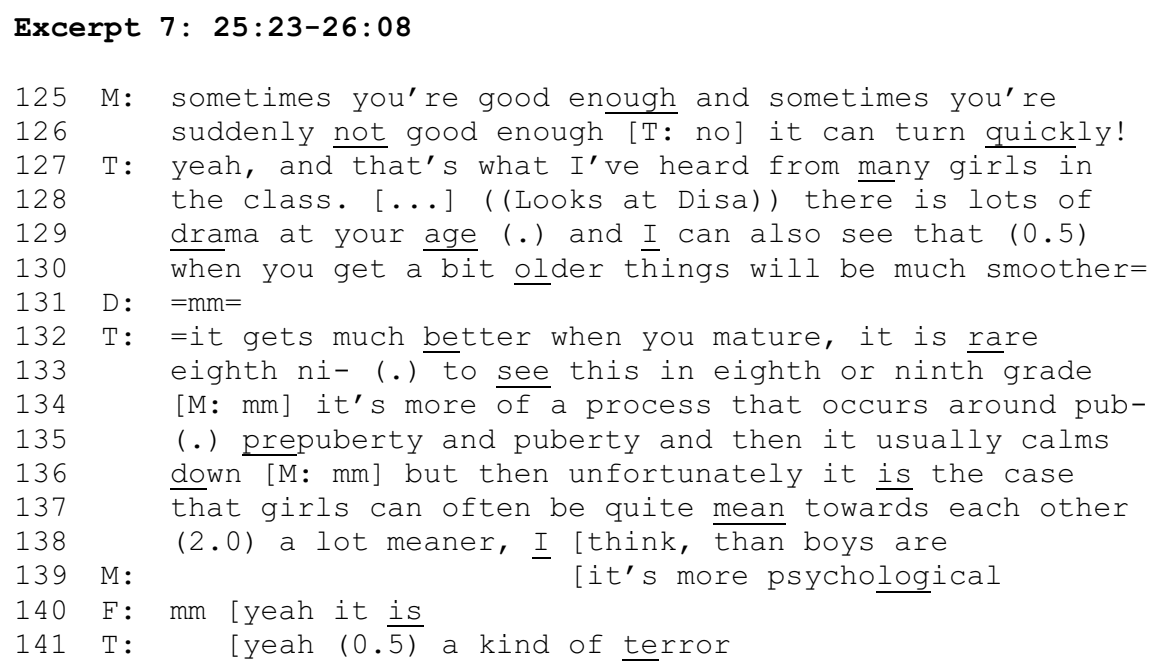

In answering the mother, the teacher again enacts the normalization repertoire, hence further deconstructing Disa as an ideal victim. First, she focuses on the ubiquity of the phenomenon, "that's what I've heard from many girls" (L127), thereby diluting Disa's victim status. Second, in describing the group dynamics as "lots of drama" (L128-129), the teacher expands her euphemistic repertoire and avoids more serious descriptors, such as "bullying," which would work against the normalization. Third, through a number of statements about the immaturity of girls of Disa's age, the teacher turns the presence of social turbulences into a developmentally "normal" problem that will eventually subside (L129-130, 132-136), hence making use of the same "hope repertoire" that was earlier deployed in relation to the boys' immaturity. However, the most serious effect for Disa is probably not the normalization as such, but the fact that Disa is described as an integral part of this rough girl culture. When the teacher earlier othered the boys (Excerpt 4), Disa was of course the civilized young woman, standing high above the immature boys, but here the teacher's use of 
"your" and "you" (L129, 130, 132) shows that Disa is actually dethroned along with the other girls. The "good friend" she claimed to be in Excerpt 1 is thereby deconstructed. This might even mean that Disa now moves into a position as non-victim, especially as a victim who merges with the offenders, i.e., where there are "faults on both sides" (Søndergaard 2012, p. 363), makes for a very bad victim (Christie 1986).

Previous research shows that providing commentary on the social environment, e.g., maliciously raising one's eyebrows, is a common activity among school girls (Søndergaard 2012), and that teachers and parents often minimize such meanness among girls by placing it in a scheme of normal development (Merten 1997). It is a furtive form of "low level bullying" (Thomson and Gunter 2008, p. 119) that teachers, according to students, often disregard. However, in this case, the teacher openly recognizes the phenomenon, and even portrays girls as "meaner ... than boys" (L138). Moreover, when answering the mother, she hyperbolically describes girls' social activities as "a kind of terror" (L141). This creates a picture of girls as "intimate enemies" (Simmons 2002, p. 39), turning them all into perpetrators and victims at the same time. More importantly, however, this exaggerated framing of girls' activities is also a way for the teacher to downplay the meanness of the boys' physical aggression towards Disa, making her less of a victim in that regard as well.

\section{Stronger Than a Victim?}

In the final example (Excerpt 8), the teacher returns to her earlier advice that Disa must stand up for herself. This becomes the beginning of a kind of "optimistic projection," a topic- shifting device that is common in relation to various forms of troubles talk (Jefferson 1988, p. 433), and perhaps particularly so in contexts where one party, as in this case, is clearly accountable.




After reintroducing the self-reliance repertoire, and describing it as "the best way" (L144), the teacher again suggests a few phrases that could be very useful for Disa (L146-148) if they were conveyed in a "clear" way (L148). This is then followed by further optimistic pep talk from the teacher and the mother: "[She has] everything to gain" (L149), "is really strong in herself" (L152), and will soon get a chance to "find a few new friends" (L159-160). The suggestive power of this argumentation also elicits affirmative responses from all participants, and it seems to prepare everyone for a topic change in all hopefulness.

However, the pep talk not only provides for a topic change, but also makes Disa less of an ideal victim. For instance, Mishna et al. (2006) argue that teachers are less likely to classify students with an ability to stand up for themselves as genuine victims of bullying. Thus, in particular the mother's statement about how strong Disa is (L152), and the compelling affirmative responses that follow (L153-158), might actually do a disservice to the latter. Certainly, there is something admirable about parents and teachers who, in line with neoliberal discourses on self-responsibility, want to see strength and resilience in the children they care for (see Sims-Schouten and Edwards 2016), but in this particular case, such a stance becomes the final step in the silencing of Disa's victimhood narrative.

\section{Discussion}

In this article, we have witnessed how a student, as part of a developmental dialogue, portrays herself as a bullying victim, but also how she immediately after this encounters a series of discursive practices, primarily enacted by her teacher, which ultimately transform her into a rejected victim. Thus, there is a striking contrast between the student's own understanding of her situation, as displayed primarily in Excerpt 1, and the understanding that develops in the ensuing interaction, throughout Excerpts 2-8. Indeed, if we allow ourselves to take the student's victimhood narrative at face value, i.e., if we accept that she is a good friend, who does not demand to be the most liked girl, and is willing to change herself if asked to, but who is still subjected to repeated and differentiating treatment by more powerful peers, then this does not only mean that she is a victim in a much wider sense than required by the most commonly used definition of bullying (Olweus 1993); it also means that, despite this, she is still not recognized as a true victim. This proves Christie's (1986) thesis that being a victim is not an objective phenomenon, but has to do with the participants' definition of the situation.

Despite focusing on a mere 5 minutes of interaction, the result of the close analyses is very revealing of the reality that self-identified bullying victims may face when they indeed go against the statistics (see Black et al. 2010) and choose to disclose their predicament to their teachers. Although the present student manages to mark off several essential victimhood components in her narrative, the sheer number of discursive repertoires that the teacher deploys in her response is quite overwhelming. Moreover, these repertoires are not only delivered deeply intertwined with each other, but are also repeated and combined with other powerful practices, e.g., the taking of the floor. Together, these practices contribute to the deconstruction of the 
student's status as a victim, and, perhaps more importantly, allow the teacher to avoid assuming full responsibility for the reported problem. From a critical perspective, the teacher in this way enacts a capillary form of power (Foucault 1980), where the conjoined forces of infinitesimal discursive practices descend over the student and her parents.

One of the most evident effects of this exertion of power is the silencing of the other participants. This is clearly noticeable in that the student, after presenting her initial narrative, barely says anything but "mm," "yeah," or "no." Moreover, this silencing is also facilitated by the fact that the student's mother and father appear as "constructive parents" (Hein 2014, p. 321). In contrast to "destructive parents," described by school personnel as uncritically siding with their own children, such parents are viewed as being carefully attentive to the teacher, perhaps taking it as a given that the professional party in the encounter has "the right to define the way things really are," as Becker (1967, p. 241) once put it. In line with this, the teacher in the analyzed case is allowed to occupy about $90 \%$ of the floor, effectively monopolizing the interpretation of the narrative. Indeed, it is even possible that the teacher interprets the student's frequent use of minimal responses, as well as the reticence of the parents, as a sign that all parties eventually identify the student as a non-victim, or at least as much less of a victim than she originally presented herself as.

More generally, the use of the repertoires and the silencing may help us to understand a number of phenomena that have repeatedly been reported in previous research on victims of bullying, e.g., that they often experience frustration in helpseeking situations (Mackay et al. 2011; Oliver and Candappa 2007; Ringrose and Renold 2010), learn to refrain from disclosing the bullying (Bjereld 2016; deLara 2012; Frisén et al. 2008), or even end up blaming themselves (Goodwin 2002; Graham and Juvonen 1998; Silberschmidt Viala 2014). Moreover, we can also begin to understand why adults, and perhaps also the victims, often tend to interpret bullying as a less serious matter than it is (Ellwood and Davies 2010; Merten 1997; Thomson and Gunter 2008), and that this, in turn, tends "to produce powerlessness rather than solutions and to let down the vulnerable child" (Hein 2016, p. 1126).

Critical victimologists refer to the above type of negative repercussions, where the original suffering of the victim is exacerbated through inadequate management, as "secondary victimization" (Stroble 2010, p. 15). More specifically, it is also possible to point to individual repertoires as highly problematic in this regard. The self-reliance repertoire used by the teacher might be a particularly good example. Although it might seem practical to recommend or teach "refusal skills" to students, exactly as the teacher does in Excerpts 4 and 8, the problem with this strategy is that it reframes the victim as the problem. If you cannot say "no," or stand up for yourself, the bullying is your own fault. Moreover, as Merten (1997) points out, this type of strategy might also facilitate further meanness among the students. Indeed, Black et al. (2010) show that victims who resort to the practice of fighting back are more likely to report polyvictimization, chronic victimization, and fear than victims who do not fight back.

So, how should we understand the use of these repertoires, this silencing, and the possible resulting secondary victimization? Although the analyses were performed on the basis of a critical view of how bullying is handled in school, it would 
be unfortunate if the studied case was reduced to a personal problem, a moral flaw residing within the teacher. For instance, the teacher's actions could be read as illustrative of her "moral disengagement" (Bandura 2016, p. 3), i.e., as a kind of rationalization that justifies inherently bad actions; in this case, bullying. Instead, the teacher's actions should be viewed as situated practices, deployed in a state of accountability. Thus, rather than trying to understand the actions by reference to possible defective internal mechanisms, the explanatory focus should instead be directed at the discursive context and the moral identities that are at stake in the meeting. The teacher stands before a student who, in front of her parents, claims to be a victim of bullying. In this situation, the teacher falls back on a number of discursive practices, which are provided by contemporary culture and which allow certain alternative readings of the events, relations, and identities under review. Other teachers might easily have reasoned in a similar way, if not for the simple reason to protect their professional identity from becoming "spoiled," i.e., being perceived as "bad teachers" (Migliaccio 2015, p. 99). Hence, if it is a problem, it is not an individual's problem, but a collective, discursive problem (see Hepburn 1997).

So, how do we go about making a change? I am certain that perceptive readers, each with their own unique experiences and understandings, will be able to identify a number of possible implications from this study. However, the remaining part of the discussion presents three implications for teachers (and other parties).

First implication: Thoroughly scrutinize your own discursive environment. Although there are solid definitions of bullying, what matters for those who disclose their own victimization is, as we have seen, how established discourses are applied in relation to such disclosures. Like bodily schemas, ways of speaking become sedimented in us through countless repetitions, and become part of our lifeworld (Merleau-Ponty 1945/2002). Thus, when a teacher encounters a bullying case, we cannot expect him or her to respond to it in a neutral way. Instead, the teacher is likely to be captive in a discursive machinery that evolves quite spontaneously, without much thought, and where highly available discursive practices and repertoires are put to use. The analyzed case shows the complexity of this machinery, and what "habitual and repetitive discursive constructions" (Ellwood and Davies 2010, p. 86) might look like in the atmosphere of their making. But although change is not particularly likely to occur spontaneously in situated interaction, careful reflection on "discursive practices at play, and the relations of power they produce" (Davies 2011, p. 282), can make a difference. It is my hope that the close analyses in this article will lead to an increased awareness of how sophisticated, subtle, and elusive discursive practices can be. In this way "normative cruelties" (Ringrose and Renold 2010, p. 575), i.e., injurious practices based on codes of behavior that are taken for granted, can be problematized and desedimented. At the very least, all school personnel need to be conscious of the discursive context in which they are situated, and how this context can adversely affect potential bullying victims (see Hepburn 1997; Jacobson 2010; Migliaccio 2015).

Second implication: Take every victimhood narrative seriously. Although I do not want to resort to teacher blaming, one of the most striking results of the analyses in this article is the lack of an inquisitive stance on the part of the teacher. An explanation for this might be that bullying is always dealing with "difficult knowledge" (Walton 2015, 
p. 27, see also Britzman 2000), i.e., knowledge about suffering that is challenging to pursue, not only because it forces you to enter into another person's painful situation, but also because it might put your own accountability at risk, and especially so if you are a teacher who is responsible for the daily well-being of children. Thus, when there is an option to choose between searching for that difficult knowledge or picking out highly available bullying repertoires, should we be surprised by the outcome? Yet, my argument is still that victimhood narratives should always, as a matter of principle, be met with an attentive, inquisitive stance. In this regard, we can learn from the testimony genre (see Blackmer Reyes and Curry Rodríguez 2012), which encourages victims to tell their stories, and bids recipients to be "unobtrusively present" (Laub 1992, p. 71). Whether used by victims of slavery (Douglass 1845/1986), concentration camp imprisonment (Levi 1959), ethnic oppression (Barrios de Chúngara 1978), child abuse (Pelzer 1995), or rape (Louis 2017), this genre allows subjugated people to acquire a voice, challenge dominating discourses, empower themselves, etc. The widespread "\#MeToo campaign" in 2017 has perhaps demonstrated this more effectively than anything. But a single bullying narrative in an isolated school meeting desperately needs the help of the teacher in order to succeed: The floor should be owned primarily by the student, questions should be asked rather than postulations issued, professional pride should be set aside.

Third implication: Solve the problem without delay. In several of the analyzed excerpts, the teacher instills hope for the future in various ways: The student will find a better position for herself in the future, she will learn to stand up for herself, people will mature, etc. As Pascoe (2013) points out, such "it gets better" talk often conveys an idealized picture of the looming adult world as a place "rife with equality and kindness" (p. 98). As such, it resembles a religious mantra that promises a better afterlife, a dream world beyond this world. However, most people in difficult circumstances probably want immediate change, and do not want to be fed with opium. This point is appositely illustrated in Lukas Moodysson's (1998) celebrated movie Fucking Åmål [English title: Show me love]. When Agnes, a bullied teenaged girl, is comforted by her father, who talks about his own victimization in school and how his current life, 25 years later, is much better, she replies in desperation: "But I'd rather be happy now than in 25 years!" The lesson to be learnt from this? Hope is for here and now-take action.

\section{Compliance with Ethical Standards}

Conflict of interest The author declares that he has no conflict of interest.

Informed Consent Informed consent was obtained from all participants included in the study.

Open Access This article is distributed under the terms of the Creative Commons Attribution 4.0 International License (http://creativecommons.org/licenses/by/4.0/), which permits unrestricted use, distribution, and reproduction in any medium, provided you give appropriate credit to the original author(s) and the source, provide a link to the Creative Commons license, and indicate if changes were made. 


\section{Appendix 1: Transcription Format}

The transcription format below is a simplified version of the one used in conversation analysis (Jefferson 2004).

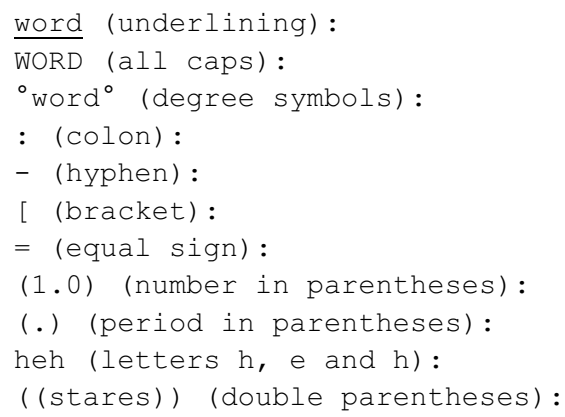

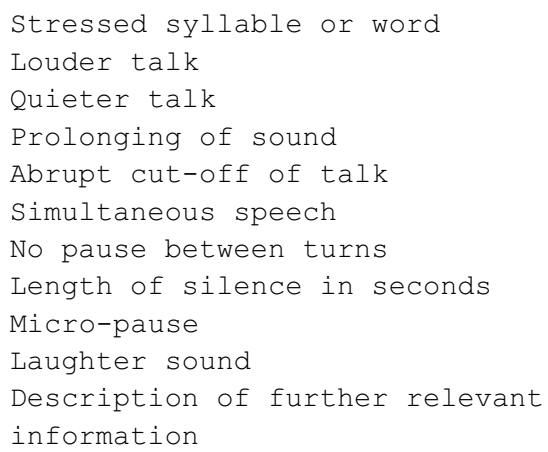

\section{References}

Bandura, A. (2016). Moral disengagement. New York: Worth Publishers.

Bansel, P., Davies, B., Laws, C., \& Linnell, S. (2009). Bullies, bullying, and power in the contexts of schooling. British Journal of Sociology of Education, 30(1), 59-69.

Barrios de Chúngara, D. (1978). Let me speak!. New York: Monthly Review Press.

Becker, H. (1967). Whose side are we on? Social Problems, 14(3), 239-247.

Bjereld, Y. (2016). The challenging process of disclosing bullying victimization: A grounded theory study from the victim's point of view. Journal of Health Psychology, 23(8), 1110-1118.

Black, S., Weinles, D., \& Washington, E. (2010). Victim strategies to stop bullying. Youth Violence and Juvenile Justice, 8(2), 138-147.

Blackmer Reyes, K., \& Curry Rodríguez, J. (2012). Testimonio: Origins, terms, and resources. Equity and Excellence in Education, 45(3), 525-538.

Britzman, D. (2000). Teacher education in the confusion of our times. Journal of Teacher Education, 51(3), 200-205.

Brown, L. M., Chesney-Lind, M., \& Stein, N. (2007). Patriarchy matters: Towards a gendered theory of teen violence and victimization. Violence Against Women, 13(12), 1249-1273.

Brunstein Klomek, A., Snir, A., Apter, A., Carli, V., Wasserman, C., Hadlaczky, G., et al. (2016). Association between victimization by bullying and direct self injurious among adolescence in Europe: A ten-country study. European Child and Adolescent Psychiatry, 25(11), 1183-1193.

Burr, V. (1995). An introduction to social constructionism. London: Routledge.

Christie, N. (1986). The ideal victim. In E. Fattah (Ed.), From crime policy to victim policy (pp. 17-30). London: MacMillan.

Copeland, W., Wolke, D., Lereya, S., Shanahan, L., Worthman, C., \& Costello, J. (2017). Childhood bullying involvement predicts low-grade systemic inflammation into adulthood. Proceedings of the National Academy of Sciences of the USA, 111(21), 7570-7575.

Craig, W., Pepler, D., \& Atlas, R. (2000). Observations of bullying in the playground and in the classroom. School Psychology International, 21(1), 22-36.

Davies, B. (2011). Bullies as guardians of the moral order or an ethic of truth? Children and Society, 25(4), 278-286.

deLara, E. (2012). Why adolescents don't disclose incidents of bullying and harassment. Journal of School Violence, 11(4), 288-305. 
Douglass, F. (1845/1986). Narrative of the life of Frederick Douglass, an American slave. New York: Penguin.

Dreyfus, H., \& Rabinow, P. (1982). Michel Foucault. Chicago: Chicago University Press.

Dussich, J., \& MaeKoya, C. (2007). Physical child harm and bullying-related behaviors: A comparative study in Japan, South Africa, and the United States. International Journal of Offender Therapy and Comparative Criminology, 51(5), 495-509.

Edwards, D., Ashmore, M., \& Potter, J. (1995). Death and furniture: The rhetoric, politics, and theology of bottom line arguments against relativism. History of the Human Sciences, 8(2), 25-49.

Ellwood, C., \& Davies, B. (2010). Violence and the moral order in contemporary schooling: A discursive analysis. Qualitative Research in Psychology, 7(2), 85-98.

Farrell, G. (2010). Repeat victimization, theories of. In B. Fisher \& S. Lab (Eds.), Encyclopedia of victimology and crime prevention (pp. 769-774). Thousand Oaks: Sage.

Foucault, M. (1980). Power/knowledge. New York: Pantheon.

Frisén, A., Holmqvist, K., \& Oscarsson, D. (2008). 13-year-olds' perception of bullying: Definitions, reasons for victimisation, and experience of adults' response. Educational Studies, 34(2), 105-117.

Gästrin, J. (1946). Skolåldern [The school age]. In T. Husén, M. Israel, S. Marklund, \& G. Blume-Westerberg (Eds.), Barnen [The Children] (pp. 103-118). Stockholm: Bonniers.

Gilbert, N., \& Mulkay, M. (1982). Warranting scientific belief. Social Studies of Science, 12(3), 383-408.

Goodey, J. (2005). Victims and victimology. Harlow: Pearson Longman.

Goodwin, M. (2002). Exclusion in girls' peer groups: Ethnographic analysis of language practices on the playground. Human Development, 45(6), 392-415.

Graham, S., \& Juvonen, J. (1998). Self-blame and peer victimization in middle school: An attributional analysis. Development Psychology, 34(3), 587-599.

Hamarus, P., \& Kaikkonen, P. (2008). School bullying as a creator of pupil peer pressure. Educational Research, 50(4), 333-345.

Hein, N. (2014). Parental positions in school bullying: The production of powerlessness in home-school cooperation. In R. Schott \& D. M. Søndergaard (Eds.), school bullying (pp. 301-329). New York: Cambridge University Press.

Hein, N. (2016). New perspectives on the positioning of parents in children's bullying at school. British Journal of Sociology of Education, 38(8), 1125-1138.

Hepburn, A. (1997). Teachers and secondary school bullying: A postmodern discourse analysis. Discourse and Society, 8(1), 27-48.

Hutchby, I., \& Wooffitt, R. (2008). Conversation analysis (2nd ed.). Cambridge: Polity Press.

Jacobson, R. (2010). Narrating characters: The making of a school bully. Interchange, 41(3), 255-283.

Jaspers, K. (1959/1963). General psychopathology. Manchester: Manchester University Press.

Jefferson, G. (1988). On the sequential organization of troubles-talk in ordinary conversation. Social Problems, 35(4), 418-441.

Jefferson, G. (2004). Glossary of transcript symbols with an introduction. In G. Lerner (Ed.), Conversation analysis (pp. 13-31). Amsterdam: John Benjamins.

Jensen, S. (2011). Othering, identity formation, and agency. Qualitative Studies, 2(2), 63-78.

Laub, D. (1992). Bearing witness or the vicissitudes of listening. In S. Felman \& D. Laub (Eds.), Testimony (pp. 57-74). New York: Routledge.

Levi, P. (1959). If this is a man. New York: Orion Press.

Louis, É. (2017). History of violence. New York: Farrar Straus Giroux.

Maccoby, E. (2000). Perspectives on gender development. International Journal of Behavioral Development, 24(4), 398-406.

Mackay, G., Carey, T., \& Stevens, B. (2011). The insider's experience of long-term peer victimization. Australian Journal of Guidance and Counselling, 21(2), 154-174.

McGarry, R., \& Walklate, S. (2015). Victims. London: Routledge.

Merleau-Ponty, M. (1945/2002). Phenomenology of perception. London: Routledge.

Merten, D. (1997). The meaning of meanness: Popularity, competition, and conflict among junior high school girls. Sociology of Education, 70(3), 175-191.

Migliaccio, T. (2015). Teacher engagement with bullying: Managing an identity within a school. Sociological Spectrum, 35(1), 84-108.

Mishna, F., Pepler, D., \& Weiner, J. (2006). Factors associated with perceptions and responses to bullying situations by children, parents, teachers, and principals. Victims and Offenders, 1(3), 255-288.

Moodysson, L. (1998). Fucking Åmål [English title: Show me love]. Stockholm: Memfis Film. 
Mythen, G. (2007). Cultural victimology: Are we all victims now? In S. Walklate (Ed.), Handbook of victims and victimology (pp. 464-483). Cullopmton: Willan.

Oliver, C., \& Candappa, M. (2007). Bullying and the politics of "telling”. Oxford Review of Education, $33(1), 71-86$.

Olweus, D. (1973). Hackkycklingar och översittare [Bullies and whipping boys]. Stockholm: Almqvist och Wiksell.

Olweus, D. (1993). Bullying at school. Oxford: Blackwell.

Osbeck, C., Holm, A.-S., \& Wernersson, I. (2003). Kränkningar i skolan [Harassment in school]. Gothenburg: University of Gothenburg.

Pascoe, C. J. (2013). Notes on a sociology of bullying: Young men's homophobia as gender socialization. QED: A Journal in GLBTQ Worldmaking, 1(1), 87-104.

Pelzer, D. (1995). A child called “it”. Deefiled Beach: Health Communications.

Potter, J. (1996). Representing reality. London: Sage.

Rigby, K. (1995). Preventing peer victimisation in schools. In C. Sumner, M. Israel, M. O'Connell, \& R. Sarre (Eds.), International victimology (pp. 303-311). Canberra: Australian Institute of Crimonology.

Ringrose, J., \& Renold, E. (2010). Normative cruelties and gender deviants: The performative effects of bully discourses for girls and boys in school. British Educational Research Journal, 36(4), 573-596.

Sacks, H. (1984). Notes on methodology. In M. Atkinson \& J. Heritage (Eds.), Structures of social action (pp. 21-27). Cambridge: Cambridge University Press.

Salmivalli, C., Lappalainen, M., \& Lagerspetz, K. (1998). Stability and change of behavior in connection with bullying in schools: A two-year follow-up. Aggressiv Behavior, 24(3), 205-218.

Schegloff, E. (1996). Confirming allusions: Toward an empirical account of action. American Journal of Sociology, 102(1), 161-216.

SFS. (2003). The ethical review act. Retrieved December 6, 2017 from http://www.epn.se/media/2348/ the_ethical_review_act.pdf.

Silberschmidt Viala, E. (2014). "It there something wrong with me?" A context-sensitive analysis of school bullying. In R. Schott \& D. M. Søndergaard (Eds.), School bullying (pp. 361-386). New York: Cambridge University Press.

Simmons, R. (2002). Odd girl out. New York: Harcourt.

Sims-Schouten, W., \& Edwards, S. (2016). "Man up!" bullying and resilience within a neoliberal framework. Journal of Youth Studies, 19(10), 1382-1400.

Smith, P., Cowie, H., Olafsson, R., \& Liefooghe, A. (2002). Definitions of bullying. Child Development, 73(4), 1119-1133.

Smith, P., \& Shu, S. (2000). What good schools can do about bullying. Childhood, 7(2), 193-212.

Søndergaard, D. M. (2012). Bullying and social exclusion anxiety in school. British Journal of Sociology of Education, 33(3), 355-372.

Stake, R. (1978). The case study method in social inquiry. Educational Researcher, 7(2), 5-8.

Stroble, R. (2010). Becoming a victim. In S. Shoham, P. Knepper, \& M. Kett (Eds.), International handbook of victimology (pp. 3-25). Boca Raton: CRC Press.

Swedish Research Council. (2011). Good research practice. Stockholm: Swedish Research Council.

Takizawa, R., Maughan, B., \& Arseneault, L. (2014). Adult health outcomes of childhood bullying victimization. American Journal of Psychiatry, 171(7), 777-784.

Thomson, P., \& Gunter, H. (2008). Researching bullying with students: A lens on everyday life in an "innovative school". International Journal of Inclusive Education, 12(2), 185-200.

Volk, A., Dane, A., \& Marini, Z. (2014). What is bullying? A theoretical redefinition. Developmental Review, 34(4), 327-343.

Walton, G. (2015). Bullying and the philosophy of shooting freaks. Confero, 3(2), 17-35.

Wolke, D., Copeland, W., Angold, A., \& Costello, J. (2013). Impact of bullying in childhood on adult health, wealth, crime, and social outcomes. Psychological Science, 24(10), 1958-1970.

Publisher's Note Springer Nature remains neutral with regard to jurisdictional claims in published maps and institutional affiliations. 